\title{
X-linked adrenoleukodystrophy in a pediatric patient: A case report
}

\author{
Graciela A. López-Uriarte1,2,3, Leonor G. Hinojosa-Amaya ${ }^{1,2,3}$, Laura G. Peña-Balboa ${ }^{1,2,3}$, and \\ Efrain de J. Medina-Cruz'1,2,3* \\ ${ }^{1}$ Department of Genetics, Universidad Autónoma de Nuevo León, Monterrey, Nuevo León; ${ }^{2}$ Department of Pediatrics, Universidad Autónoma de \\ Nuevo León, Monterrey, Nuevo León; ${ }^{3}$ Servicio de Cirugía Pediátrica Hospital Civil de Guadalajara "Fray Antonio Alcalde", Guadalajara, Jalisco, \\ Mexico
}

\begin{abstract}
$X$-linked adrenoleukodystrophy (X-ALD) is a peroxisomal disorder caused by mutations in the ABCD1 gene leading to the accumulation of very long-chain fatty acids. A 6-year-old male started his condition 6 months ago with developmental regression and loss of visual acuity. Physical examination showed hyperpigmentation in the folds and strabismus of the left eye; ophthalmoscopy showed bilateral optic nerve atrophy, decreased osteotendinous reflexes, and ataxic gait. Adrenal function was evaluated, finding elevated adrenocorticotropic hormone (ACTH). It was decided to start hormone replacement therapy, and he was sent to the department of genetics, who started treatment with Lorenzo's oil. He presented an infectious condition requiring hospitalization; 1 week after this event, he attended pediatric endocrinology with new ACTH results showing a poor response to treatment, doses were adjusted. Three months later, he came with a deterioration of symptoms, so a new treatment was started and new studies were requested. The clinical presentation, in this case, is atypical to X-ALD. The progression of the disease is rapid with characteristics similar to MLD, which implies a greater challenge in the diagnosis.
\end{abstract}

Key words: X-linked adrenoleukodystrophy. Addison's disease. Adrenal insufficiency. Peroxisomal disease. Metachromatic leukodystrophy.

\section{Introduction}

X-linked adrenoleukodystrophy (X-ALD) is the most common peroxisomal disorder, with an estimated incidence of 1 in 21,000 hemizygotes and 1 in 16,800 heterozygotes ${ }^{1}$. It is caused by mutations in the ABCD1 gene, which codifies the ALDP peroxisomal membrane protein, which is in charge of transmembrane transportation of (very) long-chain fatty acids (VLCFA; $\geq \mathrm{C} 22)^{2}$. $A$ defect in the ALDP impacts with elevated VLCFA levels in plasma and tissue, with a preference in the white matter of the brain, myelin, and suprarenal glands ${ }^{2}$. The clinical spectrum of males with $A L D / X$ varies from isolated adrenocortical failure that progresses slowly toward a myelopathy up to a catastrophic brain demyelination. Most heterozygote females will develop symptoms at around 60 years of age. In individual patients, the course of the disease remains unpredictable ${ }^{3}$.

\section{Case presentation}

Six-year-old male with no significant medical history. His current condition began 6 months prior to his initial assessment with loss of previously acquired skills such as writing, drawing and cutting. Two months prior, anhedonia and ataxic gait were added to the signs and

\section{Correspondence:}

*Efrain de J. Medina-Cruz

E-mail: efrainmedinacruz@gmail.com
Available online: $28-06-2021$

Date of reception: 11-11-2020

Date of acceptance: 09-03-2021 DOI: 10.24875/RMU.20000083
Medicina Universitaria. 2021;23(2):61-65 www.medicinauniversitaria.org

(165e CC BY-NC-ND license (http://creativecommons.org/licenses/by-nc-nd/4.0/). 
symptoms. Subsequently, dyslalia and loss of visual acuity appeared. During the physical examination, he presented strabismus of the left eye and ataxic gait; during ophthalmoscopy, he displayed atrophy of the bilateral optic nerve and pupil flattening. He also presented diminished osteotendinous reflexes in the lower left limb, hyperpigmentation in the axillar fold, groin, and neck, tanner two male genitals, and no macrogenitosomia; the rest of the physical examination was normal.

Arylsulfatase in urine was requested with a result of $31.5 \mathrm{U} / \mathrm{ml}$ (normal: $\geq 19 \mathrm{U} / \mathrm{ml}$ ), which ruled out metachromatic leukodystrophy (MLD) as a differential diagnosis. In addition, a result of adrenocorticotropic hormone (ACTH) $2451 \mathrm{pg} / \mathrm{ml}$ was obtained (normal: $12-76 \mathrm{pg} / \mathrm{ml}$ ). Cortisol and serum electrolytes were within normal parameters for his age. A month later, he was sent to endocrinology to begin management with prednisolone at physiological doses. A week later, he was referred to the department of genetics, where they began treatment with Lorenzo's oil $(60 \mathrm{ml} /$ day, $3 \mathrm{ml} / \mathrm{kg} /$ day). Four weeks after his care, he presented influenza symptoms, requiring hospitalization for a week. Subsequently, a week after being discharged, he attended the department of endocrinology with new laboratory results: ACTH $2234 \mathrm{pg} / \mathrm{ml}$, cortisol $6.59 \mathrm{ug} / \mathrm{dl}$ (normal: $5-25 \mu \mathrm{g} / \mathrm{dl}$ ), androstenedione < $0.3 \mathrm{nl} / \mathrm{dl}$ (normal), DHEA-s $1.171 \mu \mathrm{g} / \mathrm{dl}$ (normal), and testosterone $<0.25 \mathrm{ng} / \mathrm{ml}$ (normal). Consequently, an increase in prednisolone dose to stress levels was required.

Three months later, he attended the department of genetics, where deterioration in cognitive, spasticity, and rigidity was evidenced, with a loss of sphincter control. Sequencing of the ABCD1 gene was requested (xq28): VLCFA in plasma C26:0 $1.33 \mu \mathrm{g} / \mathrm{ml}$ (normal $<0.31$ ), C24:0/C22 $1.80 \mu \mathrm{mol} / \mathrm{L}$ (normal $<0.94$ ), and $\mathrm{C} 26 / \mathrm{C} 22: 00.12 \mu \mathrm{mol} / \mathrm{L}$ (normal < 0.014).

$\mathrm{He}$ attended the department of endocrinology 2 months later with a result of ACTH in $983.6 \mathrm{pg} / \mathrm{ml}$. They began management with fludrocortisone as a result of the poor response to prednisolone at a supraphysiological dose. Moreover, therapy with lovastatin $20 \mathrm{mg} /$ day was started. Monthly follow-up continued for 6 months, where the patient reduced the speed of the progression of symptoms with accentuated treatment, yet a poor prognosis remained.

\section{Discussion}

Natural X-ALD evolution allows us to distinguish different phenotypes (neonatal and asymptomatic primary suprarenal failure, childhood cerebral, and adrenomyeloneuropathy [AMN]), which develop progressively, exposing a clinical presentation spectrum ${ }^{1}$. Suprarenal failure occurs in between 80 and $86 \%$ of children between 3 and 10 years of age. Of these, $35-40 \%$ may develop childhood cerebral adrenoleukodystrophy (Table 1$)^{2}$. CALD shows a peak of incidence at 8 years old, presenting itself as quickly progressing demyelination, secondary to a metabolic defect due to VLCFA increase. Moreover, it leads to axonal degeneration and oxidative stress ${ }^{3,4}$. Its onset is insidious and it presents itself with deficits in cognitive skills including visuospatial and visuomotor functions or alterations in attention or reasoning, as well as presenting clinical data characteristic of Addison syndrome, such as skin fold hyperpigmentation'.

In this particular case, the patient presented a rapid progressive deterioration as a result of a loss of visual acuity in $<2$ months along with divergent strabismus, with clinical manifestations expected from a childhood cerebral phenotype meeting the characteristics of a progressive neurodecompensation: changes in behavior, decrease in school performance, dementia, cortical blindness, seizures, and quadriparesis; as the disease progresses, more apparent neurological alterations occur, including hyperactive or retracted behavior, apraxia, astereognosis, hearing impairment, decreased visual acuity, hemiparesis or spastic quadriparesis, cerebellar ataxia, or seizures, with coma and death in 2 or 3 years ${ }^{2,3}$. Onset of ataxic gait and atrophy of the optic nerve allows us to think of the differential diagnosis of MLD since both demyelination diseases are caused by a dysfunction in the degradation of peroxisomal and lysosomal lipids (Table 2) 4 .

Different ophthalmological manifestations have been described for each presentation of X-ADL, which allows us to differentiate the patient's clinical picture ${ }^{5}$. In the neonatal presentation, there are more epicanthic folds, esotropia, nystagmus, cataracts, optical atrophy, and an anomaly of the pigment of the retina described as ocular fundus with leopard spots (subretinal hyperreflective nodules). In CALD, ocular signs are paleness of the optical disc, demyelination of any part of the visual portion from the optic nerve to the visual cortex, loss of vision, and optic nerve atrophy. Finally, in the AMN, this shows dysfunction in the visual system but is distinguishable due to alterations in the RMN in the optical path, the most common being hyperintensity in T2 of the lateral geniculated body or optical radiations ${ }^{5}$.

An imaging study like the optical coherence tomography allows us to identify injuries and make measurements for 
Table 1. X-ALD infant cerebral phenotype, pathogenesis, and clinical manifestations of adrenal insufficiency

\begin{tabular}{|c|c|c|c|c|c|}
\hline Phenotype & \multicolumn{2}{|l|}{ Clinical presentation } & Age of onset & Frequency & Treatment \\
\hline $\begin{array}{l}\text { Cerebral ALD in } \\
\text { Infants }\end{array}$ & \multicolumn{2}{|c|}{$\begin{array}{l}\text { Progressive brain demyelination characterized by } \\
\text { hyperactivity, impulsivity, and decreased school } \\
\text { performance (may be misdiagnosed as attention } \\
\text { deficit hyperactivity disorder); cognitive deficits } \\
\text { can be observed; the onset of inflammation leads } \\
\text { to progressive functional decline to a vegetative } \\
\text { state within 2-5 years }\end{array}$} & $4-8$ years & $30-35 \%$ & \multirow{3}{*}{$\begin{array}{l}\text { - Allogeneic } \\
\text { hematopoietic } \\
\text { stem cell } \\
\text { transplantation } \\
\text { - Bone marrow } \\
\text { transplant } \\
\text { - Metabolic } \\
\text { modulators } \\
\text { - Lorenzo's oil } \\
\text { - Antioxidant } \\
\text { therapy }\end{array}$} \\
\hline Pathogenesis & Mutation & Characteristics & Cells affected & Mechanism & \\
\hline$X-A L D$ & ABCD1 & $\begin{array}{l}\text { Parieto-occipital } \\
\text { demyelination. } \\
\text { White matter } \\
\text { myelin and axons in } \\
\text { the spinal cord }\end{array}$ & $\begin{array}{l}\text { Microglia, } \\
\text { oligodendrocyte }\end{array}$ & $\begin{array}{l}\text { Active } \\
\text { transportation } \\
\text { of VLCFA to the } \\
\text { peroxisome }\end{array}$ & \\
\hline $\begin{array}{l}\text { Clinical } \\
\text { manifestations }\end{array}$ & $\begin{array}{l}\text { Chronic signs and } \\
\text { symptoms }\end{array}$ & $\begin{array}{l}\text { Acute signs and } \\
\text { symptoms }\end{array}$ & Frequency & $\begin{array}{l}\text { Laboratory } \\
\text { alterations }\end{array}$ & Treatment \\
\hline $\begin{array}{l}\text { Suprarenal } \\
\text { insufficiency }\end{array}$ & $\begin{array}{l}\text { Fatigue, weakness } \\
\text { Weight loss/growth } \\
\text { retardation } \\
\text { Anorexia/decreased } \\
\text { appetite } \\
\text { Intermittent abdominal pain } \\
\text { Orthostatic hypotension } \\
\text { Hyperpigmentation } \\
\text { Loss of pubic and armpit } \\
\text { hair }\end{array}$ & $\begin{array}{l}\text { Severe fatigue } \\
\text { Nausea/Vomiting } \\
\text { Abdominal pain } \\
\text { Dehydration } \\
\text { Hypotension } \\
\text { Altered mental } \\
\text { state/delirium } \\
\text { Signs/symptoms of } \\
\text { infection or other } \\
\text { cause of } \\
\text { physiological stress }\end{array}$ & $70-90 \%$ & $\begin{array}{l}\text { Elevated ACTH } \\
\text { Low cortisol } \\
\text { Mild } \\
\text { hyponatremia } \\
\text { Hypoglycemia } \\
\text { Hypercalcemia } \\
\text { Neutropenia, } \\
\text { eosinophilia, } \\
\text { lymphocytosis } \\
\text { Mild } \\
\text { normocytic } \\
\text { anemia }\end{array}$ & $\begin{array}{l}\text { Corticosteroid } \\
\text { replacement } \\
\text { therapy }\end{array}$ \\
\hline
\end{tabular}

ALD: adrenoleukodystrophy, X-ALD: X-linked adrenoleukodystrophy, VLCFA: very long-chain fatty acid, ACTH: adrenocorticotropic hormone.

each presentation of the X-AD. In the neonatal form, we can see external retina atrophy and an enlarged peripapillary layer of fibers of the optic-retinal nerve (RNFL). In CADL, we can see that the thickness of the ganglion cells and internal plexiform layers is reduced. Finally, in ADM, there is bilateral thinning of the RNFL and reduction of macular volume ${ }^{5}$. This study provides evidence of active demyelization and seeks to differentiate X-ADL with other ailments that manifest spasticity where demyelization of the optic nerve is not a part of the phenotype. However, LDM does present it, but the difference is pathogenic; in $X-A D L$, a significant decrease of microglial markers is observed without continuous loss of oligodendrocytes $(\mathrm{OL})$, which indicates an early loss of microglia in pre-injury areas, and these microglial markers reappear later with astrogliosis scars ${ }^{4,5}$. On the contrary, while the specific markers of microglia are present in the first stages of LDM, subsequently, a progressive loss of microglial and phagocytic markers is produced before the loss of $\mathrm{OL}$ in the white pre-injury substance $\mathrm{C}^{4,5}$. As a result, a study of arylsulfatase in urine is necessary.
The patient's parents explained that hyperpigmentation occurred at the beginning of the first neurological data; this is characteristic of suprarenal failure. X-ALD in males is distinguished by an onset with clinical data of suprarenal failure, followed by a slow progression myeloneuropathy (AMN), usually occurring between 20 and 30 years old; on the other hand, heterozygotic females develop symptoms until they are 30 and 40 years of age, but usually show neurological deterioration posterior to 60 years of age ${ }^{1,6}$. The CALD phenotype is often diagnosed incorrectly as attention deficit disorder, which can delay diagnosis ${ }^{6}$. Histopathological studies in patients with X-ALD show white substance demyelination in the parietal occipital regions, the callous body, and loss of myelin and axons in the corticospinal, gracile, and spinocerebellar tracts of the spinal $\operatorname{cord}^{7,8}$. It is necessary to have a follow-up with brain MRIs to assess the progression of the disease. The first brain magnetic resonance ought to be performed after 12 months, and afterward, annually up to 3 years, after that every 6 months up to 10 years, and afterward every 
Table 2. Detection, monitoring, and differential diagnosis of X-ALD

\begin{tabular}{|c|c|c|c|c|c|c|}
\hline $\begin{array}{l}\text { Newborn } \\
\text { detection }\end{array}$ & $\begin{array}{l}\text { First level } \\
\text { test }\end{array}$ & Second level test & Third level test & $\begin{array}{l}\text { Average } \\
\text { concentration } \\
\text { of the three } \\
\text { values } \\
\text { (positive) }\end{array}$ & $\begin{array}{l}\text { Limit of mean } \\
\text { concentration } \\
\text { (positive) }\end{array}$ & Sequencing \\
\hline $\begin{array}{l}\text { Test for } \\
\text { HPLC-MS/ } \\
\text { MS for } \\
\text { C26:0 and } \\
\text { C24:0 LPC }\end{array}$ & $\begin{array}{c}\text { C24:0 LPC } \\
>0.175 \\
\mu \mathrm{mol} / \mathrm{L} \text { C26:0 } \\
\text { LPC } \\
>0.08 \mu \mathrm{mol} / \mathrm{L}\end{array}$ & $\begin{array}{c}\text { C26:0 LPC } \\
>0.08 \mu \mathrm{mol} / \mathrm{L} \\
\mathrm{C} 24: 0 \mathrm{LPC} \\
>0.175 \mu \mathrm{mol} / \mathrm{L}\end{array}$ & $\begin{array}{c}\text { C26:0 LPC } \\
>0.08 \mu \mathrm{mol} / \mathrm{L} \\
\text { C24:0 LPC } \\
>0.175 \mu \mathrm{mol} / \mathrm{L}\end{array}$ & $\begin{array}{l}\text { C26:0 LPC } \\
\geq 0.15 \mu \mathrm{mol} / \mathrm{L} \\
\text { C24:0 LPC } \\
\geq 0.175\end{array}$ & $\begin{array}{c}\text { C26:0 LPC } \\
>0.08-<0.15 \\
\mu \mathrm{mol} / \mathrm{L} \\
\mathrm{C} 24: 0 \mathrm{LPC} \\
\leq 0.175 \mu \mathrm{mol} / \mathrm{L}\end{array}$ & Gene ABCD1 \\
\hline Tracing & Age & АСТН & Cortisol & \multicolumn{3}{|l|}{ Management } \\
\hline \multirow[t]{4}{*}{$\begin{array}{l}\text { Adrenal } \\
\text { function }\end{array}$} & \multirow[t]{4}{*}{$<2$ years } & $>100 \mathrm{pg} / \mathrm{mL}$ & $<10 \mu \mathrm{g} / \mathrm{dL}$ & \multicolumn{3}{|c|}{$\begin{array}{l}\text { Corticotropin test. Peak cortisol }<18 \mu \mathrm{g} / \mathrm{dL} \text {. Initiate } \\
\text { corticosteroid replacement therapy }\end{array}$} \\
\hline & & $<100 \mathrm{pg} / \mathrm{mL}$ & $>5 \mu \mathrm{g} / \mathrm{dL}$ & \multicolumn{3}{|c|}{ No treatment. Reassess every $3-4$ months } \\
\hline & & $>300 \mathrm{pg} / \mathrm{mL}$ & $<18 \mu \mathrm{g} / \mathrm{dL}$ & \multicolumn{3}{|c|}{ Initiate corticosteroid replacement therapy } \\
\hline & & $100-299 \mathrm{pg} / \mathrm{mL}$ & $>10 \mu \mathrm{g} / \mathrm{dL}$ & \multicolumn{3}{|c|}{$\begin{array}{l}\text { Corticotropin test. Peak cortisol }<18 \mu \mathrm{g} / \mathrm{dL} \text {. Initiate } \\
\text { corticosteroid replacement therapy }\end{array}$} \\
\hline Disease & Mutation & \multicolumn{2}{|c|}{ Histopathological pattern } & \multicolumn{3}{|c|}{ Clinical presentation } \\
\hline \multirow[t]{3}{*}{ MLD } & ARSA & \multicolumn{2}{|c|}{$\begin{array}{l}\text { Sulfatide accumulation in astrocytes, } \\
\text { neurons, oligodendrocytes, and } \\
\text { Schwann cells, leading to } \\
\text { demyelination. In addition, loss of } \\
\text { acoustic ganglion neurons, alteration } \\
\text { of Purkinje cell morphology, reduction } \\
\text { of myelinated axons of the optic nerve } \\
\text { and corpus callosum, and astrogliosis } \\
\text { secondary to demyelination }\end{array}$} & \multicolumn{3}{|c|}{$\begin{array}{l}\text { MLD can present as late childhood, juvenile, or adult. Late } \\
\text { childhood MLD has a shorter life expectancy, with symptoms } \\
\text { of peripheral and central neuropathy. Evidence of } \\
\text { manifestations of demyelination occurs for up to } 2 \text { years. } \\
\text { This phenotype exhibits hearing deficits, ataxia, tremors, and } \\
\text { hypotonic paresis }\end{array}$} \\
\hline & \multicolumn{2}{|l|}{ Brain pattern } & Cells affected & Mechanism & \multicolumn{2}{|l|}{ Treatment } \\
\hline & \multicolumn{2}{|c|}{$\begin{array}{l}\text { Hyperintense signal in the corpus } \\
\text { callosum and radiant fringes of } \\
\text { normal signal within the abnormal } \\
\text { white matter }\end{array}$} & $\begin{array}{l}\text { Microglia, } \\
\text { oligodendrocyte, } \\
\text { astrocyte }\end{array}$ & Sulfatides & \multicolumn{2}{|c|}{$\begin{array}{l}\text { - Hematopoietic stem cell transplantation } \\
\text { - Umbilical cord blood transplant } \\
\text { - Bone marrow transplant }\end{array}$} \\
\hline
\end{tabular}

MLD: metachromatic leukodystrophy, ARSA: arylsulfatase A, HPLC-MS/MS: high-performance liquid chromatography tandem mass spectrometry, LPC: lysophosphatidylcholine, ACTH: adrenocorticotropic hormone, X-ALD: X-linked adrenoleukodystrophy.

year $^{1,9}$. Brain MRIs show cerebral injuries, which usually precede clinical symptoms ${ }^{9}$.

Patients are usually asymptomatic at birth; likewise, it is difficult to detect it in female patients who are carriers. This, combined with the potentially deathly progression of CALD, puts X-ALD in an ideal condition for detection in newborns ${ }^{10}$.

Newborn screening began to be implemented in 2016 in the US ${ }^{11}$. A high-performance liquid chromatography test is used: first level MS (mass spectrometry)/MS in negative ions mode for the initial screening of the samples. Once the patient is identified, sequencing of the ABCD1 gene is requested to confirm diagnosis (Fig. 2) ${ }^{10,11}$. The patient and his/her family are referred to receive counseling; similarly, confirmation tests are performed in all members that may require them, and suprarenal function is assessed. Biochemical evidence of suprarenal failure has been proven to exist in newborn patients from 5 weeks and at 4.5 months. Today, the objective is a screening frame of cortisol and ACTH approximately every 3-4 months during the first 2 years and every 4-6 months after 2 years of age (Fig. 2) $)^{10,11}$.

Suprarenal failure management begins with corticosteroid replacement; having an early follow-up with cortisol and ACTH screening allows replacement with glucocorticoids in time, which prevents a suprarenal crisis episode ${ }^{1,3}$. Hydrocortisone is the glucocorticoid of choice in children since it has less suppression of growth. It should begin with a stress dose of $8-12 \mathrm{mg} / \mathrm{m}^{2} / \mathrm{day}$ divided into three daily doses. In case of mineralocorticoid 
deficiency, a dose of fludrocortisone at $0.1 \mathrm{mg} /$ day is suggested ${ }^{3}$. Similarly, allogenic transplant of hematopoietic stem cells has shown effective results for brain ALD in the early stages of the disease (Loes $0.5-9$ and a neurological function score $\leq 1$ ), managing to stop the progression of the disease at a brain level. However, symptomatic patients with a Loes score of $\geq 10$ before the transplant produce unfavorable results ${ }^{9,12}$.

Alternative therapies such as Lorenzo's Oil, in addition to a decrease in the intake of fats in the diet, reduce the plasma levels of VLCFA. Still, they do not prevent the progression of CALD, while metabolic modulators like bezafibrate provide a reduction in the VLCFA in ALD fibroblasts, yet not in plasma. Recently, a combination of multiple antioxidants in high doses proved to normalize biomarkers from oxidative damage and inflammation in X-ALD ${ }^{1,12}$.

\section{Conclusion}

The clinical presentation of this case is atypical to $X$-ALD. The progression of the disease is characteristic of MLD, which made establishing a diagnosis more complex. It is necessary to differentiate clinical manifestations specific to each disease. Moreover, the support of additional laboratory tests is required to corroborate a diagnosis. The approach ought to be performed early in asymptomatic patients, allowing for the establishment of effective therapeutic strategies.

\section{Ethical responsibilities}

People and animal protection. The authors declare that there were no experiments performed on human beings or animals for this research.
Data confidentiality. The authors declare that no patient data appear in this document.

Right to privacy and informed consent. The authors declare that no patient data appear in this document.

\section{References}

1. Eng L, Regelmann MO. Adrenoleukodystrophy in the era of newborn screening. Curr Opin Endocrinol Diabetes Obes. 2020;27: 47-55.

2. Huffnagel IC, Laheji FK, Aziz-Bose R, Tritos NA, Marino R, Linthorst GE, et al. The natural history of adrenal insufficiency in $\mathrm{X}$-linked adrenoleukodystrophy: an international collaboration. J Clin Endocrinol Metab. 2019;104:118-26.

3. Turk BR, Theda C, Fatemi A, Moser AB. X-linked adrenoleukodystrophy: pathology, pathophysiology, diagnostic testing, newborn screening and therapies. Int J Dev Neurosci. 2020;80:52-72.

4. Garcia LM, Hacker JL, Sase S, Adang L, Almad A. Glial cells in the driver seat of leukodystrophy pathogenesis. Neurobiol Dis. 2020;146:105087.

5. de Freitas JL, Rezende Filho FM, Sallum JM, França MC Jr., Pedroso JL, Barsottini OG. Ophthalmological changes in hereditary spastic paraplegia and other genetic diseases with spastic paraplegia. J Neurol Sci. 2020;409:116620.

6. Berger J, Gärtner J. X-linked adrenoleukodystrophy: clinical, biochemical and pathogenetic aspects. Biochim Biophys Acta. 2006;1763:1721-32.

7. Kemp S, Wanders R. Biochemical aspects of X-linked adrenoleukodystrophy. Brain Pathol. 2010;20:831-7.

8. Engelen M, Kemp S, Poll-The BT. X-linked adrenoleukodystrophy: pathogenesis and treatment. Curr Neurol Neurosci Rep. 2014; $14: 486$.

9. Miller WP, Mantovani LF, Muzic J, Rykken JB, Gawande RS, Lund TC, et al. Intensity of MRI gadolinium enhancement in cerebral adrenoleukodystrophy: a biomarker for inflammation and predictor of outcome following transplantation in higher risk patients. AJNR Am J Neuroradiol. 2016;37:367-72

10. Lee S, Clinard K, Young SP, Rehder CW, Fan Z, Calikoglu AS, et al. Evaluation of $X$-linked adrenoleukodystrophy newborn screening in North Carolina. JAMA Netw Open. 2020;3:e1920356.

11. Regelmann MO, Kamboj MK, Miller BS, Nakamoto JM, Sarafoglou K, Shah S, et al. Adrenoleukodystrophy: guidance for adrenal surveillance in males identified by newborn screen. J Clin Endocrinol Metab. 2018;103:4324-31.

12. Eichler F, Duncan C, Musolino PL, Orchard PJ, De Oliveira S, Thrasher AJ, et al. Hematopoietic stem-cell gene therapy for cerebral adrenoleukodystrophy. N Engl J Med. 2017;377:1630-8. 